-Full Paper-

\title{
Immunohistochemical Localization of Steroidogenic Enzymes in the Testis of the Sika Deer (Cervus nippon) During Developmental and Seasonal Changes
}

\author{
Daisuke HAYAKAWA ${ }^{1,2)}$, Motoki SASAKI ${ }^{1,2)}$, Masatsugu SUZUKI ${ }^{2,3)}$, Toshio TSUBOTA ${ }^{4)}$, \\ Hiromasa IGOTA $^{5)}$, Koichi KAJI ${ }^{6)}$ and Nobuo KITAMURA ${ }^{1,2)}$
}

\begin{abstract}
${ }^{1)}$ Laboratory of Veterinary Anatomy, Department of Basic Veterinary Medicine, Obihiro University of Agriculture and Veterinary Medicine, Obihiro 080-8555, 2) United Graduate School of Veterinary Medicine, Gifu University, Gifu 5011193, ${ }^{3)}$ Laboratory of Zoo and Wildlife Medicine, Faculty of Applied Biological Science, Gifu University, Gifu 501-1193, ${ }^{4)}$ Department of Environmental Veterinary Science, Graduate School of Veterinary Medicine, Hokkaido University, Sapporo 060-0818, 5) Department of Biosphere and Environment Sciences, Rakuno Gakuen University, Ebetsu 069-8501 and ${ }^{6)}$ Laboratory of Wildlife Conservation, Division of Ecosciences, Institute of Symbiotic Science and Technology, Tokyo University of Agriculture and Technology, Fuchu 183-8509, Japan
\end{abstract}

\begin{abstract}
Testicular steroidogenesis and spermatogenesis during developmental and seasonal changes were investigated in male sika deer (Cerous nippon), a short-day seasonal breeder, to clarify the physiological mechanisms for reproductive function. The immunohistochemical localization of steroidogenic enzymes (P450scc, P450c17, 3 $\beta$ HSD and P450arom), spermatogenesis and cell proliferation were analyzed in the testes of fetal (164 to 218 days of fetal age), fawn (0 years old), yearling (1 year old) and adult (more than 2 years old) male sika deer. Three kinds of steroidogenic enzymes, P450scc, P450c17 and 3 $\beta$ HSD, essential for the synthesis of testosterone were located only in the Leydig cells of the testes from the fetal period, and these localizations did not change during developmental or seasonal stages. Immunoreactivity for P450arom, a key enzyme converting testosterone to estradiol, was also localized only in the Leydig cells of testes but was also further limited to the testes of yearlings and adults. Seminiferous tubules had already formed in the fetal testes examined in the present study. Spermatogenesis started in yearlings and was more active in the breeding season. In the adult sika deer testes, the Leydig cells, which displayed immunoreactivities for steroidogenic enzymes, changed to have more cytoplasm in the breeding season than in the non-breeding season. Cell proliferation of Leydig cells was hardly observed in adult testes during seasonal changes. The present results suggested that sika deer testes start to synthesize testosterone from the fetal period, that seasonal changes in testosterone and estradiol syntheses are dependent on the quantitative variation of steroidogenic enzymes synchronized with the size of Leydig cells and that estradiol synthesized in yearling and adult testes makes a contribution to the initiation and recrudescence of spermatogenesis and spermiogenesis in the sika deer.
\end{abstract}

Key words: Developmental change, Seasonal change, Sika deer, Steroidogenic enzyme, Testis

(J. Reprod. Dev. 56: 117-123, 2010)

M any species of the Cervidae are short-day seasonal breeders. It has been reported that the red deer (Cervus elaphus) shows clear seasonal changes in the gonads, reproductive tracts, accessory genital glands and various other organs [1]. The sika deer (Cervus nippon) is the only Cervidae inhabiting Japan except for a feral foreign cervid, Reeves' muntjac (Muntiacus reevesi). This species is also a short-day seasonal breeder, and the rut is observed from October to December, at which point the testicular weight and diameter of the seminiferous tubules are increased in males [2].

Reproductive events are maintained through intricate regulatory mechanisms induced by regulatory factors, such as hormones and growth factors. Therefore, comprehensive studies on reproductive functions are necessary to understand the complicated interactions between these factors, and reproductive techniques based on the

Received: June 11, 2009

Accepted: October 9, 2009

Published online in J-STAGE: November 19, 2009

(C2010 by the Society for Reproduction and Development

Correspondence: M Sasaki (e-mail: sasakim@obihiro.ac.jp) elucidated functions will make conservation of endangered animals and wildlife management possible.

In males, sex steroid hormones, such as androgen and estrogen, are synthesized in the testes, of which steroidogenesis participates with several steroidogenic enzymes [3]. Androgen operates on not only the testes themselves but also accessory genital glands by way of its receptor (androgen receptor), regulating the differentiation and growth of these organs and spermatogenesis in the testes [4]. Estrogen is also concerned with development and spermatogenesis in the testes [5, 6]. Therefore, an understanding of the dynamics of sex steroid hormones is important to reveal testicular functions.

Analysis of serum concentrations of sex steroid hormones is a general approach to demonstrate an endocrinological strategy for reproduction. In several seasonal breeders, the serum concentrations of steroid hormones exhibit seasonal fluctuations [7-13]. In addition, the immunolocalization of steroidogenic enzymes in the testes has been reported to change seasonally in the black bear and northern fur seal $[12,13]$. Moreover, it has been reported that the expression of steroidogenic enzymes in the testis is different among 
Table 1. Developmental stages and number of animals used in the present study

\begin{tabular}{lllc}
\hline Developmental stage & Season & Month & Number \\
\hline Fetus (164-218 days) & Breeding season & October and November & 7 \\
Fawn (0 years old) & Non-breeding season & January & 3 \\
& Non-breeding season & July & 4 \\
Yearling (1 year old) & Breeding season & November & 4 \\
& Breeding season & October and November & 3 \\
Adult (>2 years old) & Non-breeding season & January & 10 \\
& & March & 4 \\
& & July & 4 \\
& & & 3 \\
\hline Total & & 42 \\
\hline
\end{tabular}

the developmental stages [14-17]. In the testes of adult sika deer, it has been reported that the immunohistochemical localization of steroidogenic enzymes found in the breeding season [18]. In the sika deer, the testes change in size and structure dramatically with not only sexual maturity but also seasonal transitions [2]. Therefore, fluctuations in the localization of steroidogenic enzymes in the testes may be found during developmental and seasonal changes, and these fluctuations may lead to hints that are helpful in elucidation of testicular control mechanisms.

The present study analyzed the immunohistochemical localization of steroidogenic enzymes in the testes of sika deer during developmental and seasonal changes to clarify the functional mechanisms of reproduction of male sika deer.

\section{Materials and Methods}

Testes were obtained from a total of 42 male Hokkaido sika deer (Cervus nippon yesoensis), a subspecies of the sika deer living in Hokkaido, Japan, in the districts of Nishiokoppe, Okoppe, Ohmu, Ashoro, Nakasatsunai and Nakanoshima Island between November 2002 and July 2007. Thirty-two wild male deer were hunted in October and November (breeding season) and January, March and July (non-breeding season) with official permission. Three adult males kept at a deer farm were immobilized by an injection of a mixture of ketamine hydrochloride $(1.5 \mathrm{mg} / \mathrm{kg})$ and xylazine hydrochloride $(1.2 \mathrm{mg} / \mathrm{kg})[19,20]$. After chemical immobilization, a piece of a testis was biopsied from each animal. The developmental stages and numbers of animals are shown in Table 1. The testes of seven male fetuses (164 to 218 days of fetal age) were collected from pregnant females captured between March and June. The fetal age was estimated by body weight [21]. The age of each animal after birth was estimated by branching of antlers and dentition [22], and the animals were then categorized as fawns (0 years old), yearlings (1 year old) and adults (more than 2 years old). Because Hokkaido sika deer usually give birth in June [20, 23], the ages of the deer were classified into the next category beginning in June.

The removed testes were immediately fixed in Bouin's fluid or phosphate-buffered (pH 7.2) 10\% formalin. After fixation, the tissue samples were dehydrated in a graded series of ethanol, cleared in xylene and embedded in paraffin (Paraplast Plus ${ }^{\circledR}$, Kendall, Mansfield, MA, USA). The samples were cut serially at $4 \mu \mathrm{m}$ thickness and mounted on aminopropyl-triethoxy-silane-coated slides (S8226, Matsunami Glass, Osaka, Japan). After deparaffinization, the testicular tissue sections were stained with hematoxylin and eosin ( $\mathrm{HE}$ ) to investigate the general structure and spermatogenesis.

To detect the localization of steroidogenic enzymes, the sections were stained immunohistochemically using an avidin-biotin peroxidase complex (ABC) method [24] or the ImmPRESS ${ }^{\mathrm{TM}}$ (polymerized reporter enzyme staining system) method (Vector Laboratories, Burlingame, CA, USA). The primary antibodies used in this study are summarized in Table 2. The antibodies against P450scc, P450c17, 3 $\beta$ HSD and P450arom were used in previous studies on testicular steroidogenesis [12, 15, 18, 25, 26].

For the ABC method, the deparaffinized sections were incubated with methanol containing $0.3 \% \mathrm{H}_{2} \mathrm{O}_{2}$ for $10 \mathrm{~min}$ at room temperature (RT) to block endogenous peroxidase activity and then with normal goat serum (1:50, S-1000, Vector Laboratories) for 30 min at RT to prevent nonspecific staining. The samples were incubated with each primary antibody overnight at $4 \mathrm{C}$. After an overnight incubation, the secondary antibody, biotinylated anti-rabbit IgG raised in the goat (1:200, BA-1000, Vector Laboratories), was applied for $30 \mathrm{~min}$ at RT, and then the sections were incubated with ABC for 30 min at RT (1:2, PK-6100, Vectastain Elite ${ }^{\circledR}$ ABC Kit, Vector Laboratories). The immunoreactive sites were visualized using Tris-HCl buffer ( $\mathrm{pH} 7.4$ ) containing $0.02 \%$ 3,3'-diaminobenzidine tetrahydrochloride (DAB) and $0.006 \% \mathrm{H}_{2} \mathrm{O}_{2}$. For the ImmPRESS ${ }^{\mathrm{TM}}$ method, the sections were incubated with ImmPRESS anti-rabbit IgG (MP-7401, ImmPRESS ${ }^{\mathrm{TM}}$ reagent, Vector Laboratories) for $30 \mathrm{~min}$ at RT after overnight incubation with the primary antibodies, and the binding sites were visualized using acetonitrile (SK-4700, Vector ${ }^{\circledR}$ SG Substrate Kit, Vector Laboratories).

In addition, to investigate the cellular proliferation of adult deer testes during developmental and seasonal changes, the sections were stained immunohistochemically with monoclonal antibody against rat proliferating cell nuclear antigen (PCNA; Table 2) and visualized using an $\mathrm{ABC}$ kit. For the negative controls, the sections were treated with each normal serum or $0.01 \mathrm{M}$ PBS instead of the 
Table 2. Characteristics and dilutions of primary antibodies

\begin{tabular}{|c|c|c|c|c|}
\hline Antigen & Host & Type & Dilution & Catalog No. or Source \\
\hline $\begin{array}{l}\text { Rat cholesterol side-chain cleavage } \\
\text { cytochrome P450 (P450scc) }\end{array}$ & Rabbit & Polyclonal & $1: 200$ & $\begin{array}{l}\text { AB-1244 } \\
\text { Chemicon International, Temecula, CA, USA }\end{array}$ \\
\hline $\begin{array}{l}\text { Porcine } 17 \alpha \text {-hydroxylase } \\
\text { cytochrome P450 (P450c17) }\end{array}$ & Rabbit & Polyclonal & $1: 500$ & [49] \\
\hline $\begin{array}{l}\text { Human } 3 \beta \text {-hydroxysteroid } \\
\text { dehydrogenase ( } 3 \beta \text { HSD) }\end{array}$ & Rabbit & Polyclonal & $1: 500$ & {$[50]$} \\
\hline $\begin{array}{l}\text { Human aromatase cytochrome P450 } \\
\text { (P450arom) }\end{array}$ & Rabbit & Polyclonal & $1: 500$ & {$[51]$} \\
\hline $\begin{array}{l}\text { Rat proliferating cell nuclear antigen } \\
\text { (PCNA) }\end{array}$ & Mouse & Monoclonal & $1: 100$ & $\begin{array}{l}11434 \\
\text { ICN Pharmaceuticals, Cleveland, OH, USA }\end{array}$ \\
\hline
\end{tabular}

primary antibody.

\section{Results}

\section{General structure of testis}

The testes of male sika deer showed remarkable histological changes during development. In the earliest fetal testis examined in this study (164 days of fetal age), the seminiferous tubules had already been formed. However, in the fetuses and fawns, the germ cells had not yet differentiated into spermatogenic cells, and thus spermatogenesis was not observed (Fig. 1A and B). In the fetal testis at 164 days, the interstitial tissue containing the Leydig cells was loosely dispersed among the seminiferous tubules (Fig. 1A). In the fawns, the Leydig cells were gathered, and the cytoplasm was more extensively developed (Fig. 1B).

In the yearlings, spermatozoa were not detected in July, although germ cell differentiation into spermatogenic cells had already started (Fig. 1C). On the other hand, in November, yearling deer completed spermatogenesis and began producing spermatozoa (Fig. 1D). In the adult testes, histological changes in the seminiferous epithelium were clearly shown during seasonal changes. In October and November, the seminiferous tubules were well developed and showed active spermiogenesis (Fig. 1E). In January, spermiogenesis was inactive, but a few spermatozoa were still found in the seminiferous tubules (Fig. 1F). However, in March, the seminiferous epithelium was regressed, and degenerated spermatocytes and spermatids were left out of the Sertoli cells (Fig. $1 G)$. In July, spermatogenesis recrudesced, and the seminiferous tubules were found to contain many spermatocytes and occasionally spermatids, but no spermatozoa (Fig. $1 \mathrm{H}$ ).

In the breeding season, the Leydig cells, which occupy the interstitial tissue surrounding the seminiferous tubules, contained extensive cytoplasm (Fig. 1E). In the non-breeding season, especially March, the Leydig cells were regressed, and their cytoplasm was less abundant (Fig. 1F-H). Therefore, the interstitial area became smaller in the non-breeding season than in the breeding season (Fig. 1E-H).

\section{Immunohistochemistry}

In all the testes examined in this study, the immunoreactivities for P450scc, P450c17 and 3 $\beta$ HSD were localized only in the Ley-
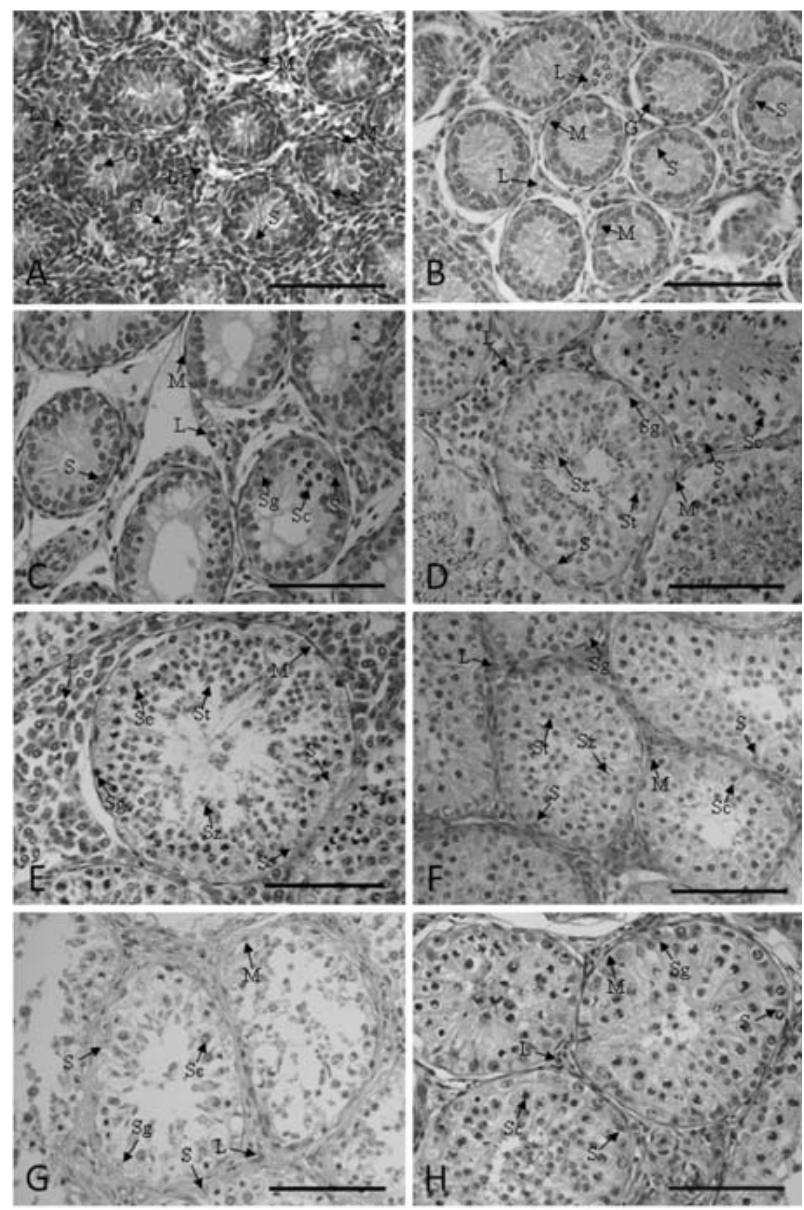

Fig. 1. General structure of the testes in the sika deer. (A) The earliest fetus, 164 days of fetal age, (B) fawn, (C, D) yearling (C, July; D, November), (E-H) adult (E, November; F, January; G, March; H, July). G: Germ cells L: Leydig cells M: Myoid cells Sg: Spermatogonia Sc: Spermatocytes St: Spermatids Sz: Spermatozoa S: Sertoli cells. Bar $=100 \mu \mathrm{m}$.

dig cells (Figs. 2 and 3). Furthermore, Leydig cells also showed immunoreactivity for P450arom, but this was limited to the testes of yearlings and adults (Fig. 4). The immunointensities of all steroidogenic enzymes, except for P450arom, did not show clear 

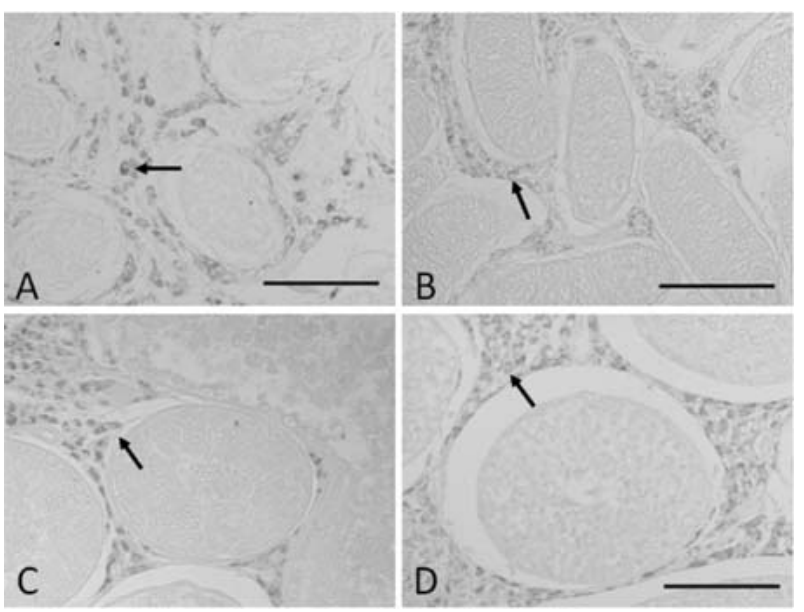

Fig. 2. Immunohistochemical localization of P450scc in the testes of the sika deer during development. Immunoreactivity for P450scc is localized only in Leydig cells (arrows) during all developmental stages. (A) Fetus, (B) fawn, (C) yearling and (D) adult in the breeding season. $\mathrm{Bar}=100 \mu \mathrm{m}$.
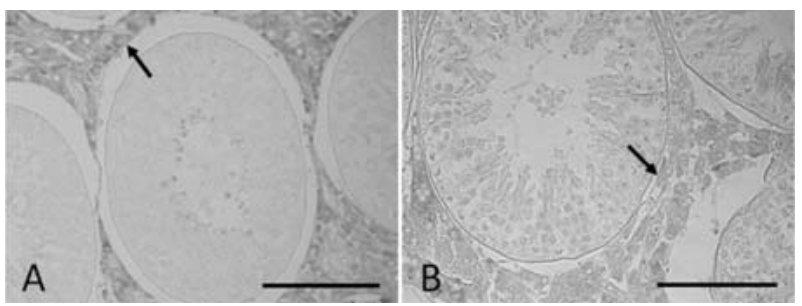

Fig. 3. Immunohistochemical localization of P450c17 and 3/HSD in the testes of adult sika deer in the breeding season. These enzymes are localized only in Leydig cells (arrows). (A) P450c17, (B) $3 \beta$ HSD. Bar $=100 \mu \mathrm{m}$.

developmental changes. However, all steroidogenic enzymes indicated strong immunoreactivities in the breeding season (Fig. 5). Moreover, in the breeding season, the Leydig cells with steroidogenic enzyme immunoreactivities became larger in size than those in the non-breeding season (Fig. 5).

In the fetal and fawn testes, the immunoreactivity for PCNA was localized in the Sertoli cells, Leydig cells, germ cells and myoid cells (Fig. 6A). However, in the yearlings and adults, the PCNAimmunoreactive Sertoli cells disappeared completely (Fig. 6B and C). In these two developmental stages, PCNA-immunoreactive Leydig cells and myoid cells were only few in number (Fig. 6B and C). On the other hand, spermatogonia and spermatocytes showed remarkable immunoreactivities for PCNA (Fig. 6B and C). In the yearlings and adults, the immunolocalization of PCNA did not differ throughout the seasonal changes (Fig. 6C and D).

\section{Discussion}

Sex steroid hormones such as testosterone and estradiol produced by steroidogenic enzymes play an essential role in

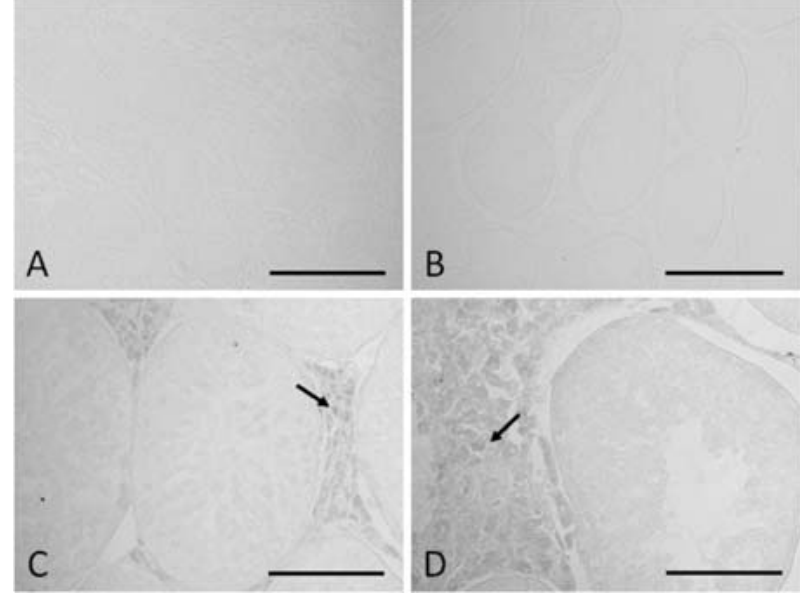

Fig. 4. Immunohistochemical localization of P450arom in the testes of the sika deer during different developmental stages. Immunoreactivity for P450arom is localized only in the Leydig cells (arrows) of yearling (C) and adult (D) deer testes in the breeding season and not in the fetus (A) or fawn (B) testes. Bar=100 $\mu \mathrm{m}$.
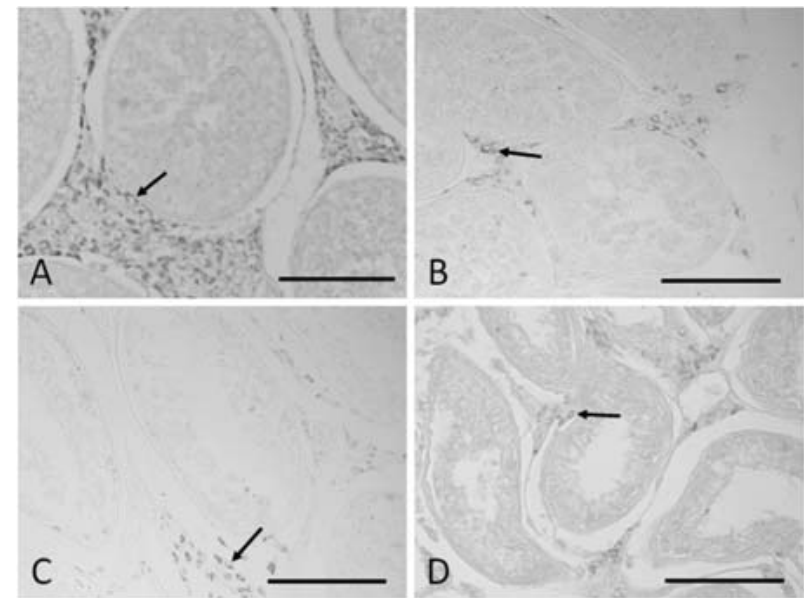

Fig. 5. Immunohistochemical localization of P450scc in the testes of adult sika deer during different seasonal periods. Immunoreactivity for P450scc is localized only in Leydig cells (arrows) and is strongest in the breeding season. (A) October, (B) January, (C) March, (D) July. Bar=100 $\mu \mathrm{m}$.

reproductive functions. It is necessary to investigate the localization of steroidogenesis in the testis of each mammalian species because the localization is different among animal species and among developmental and seasonal changes. The present study is the first histological report on the testicular steroidogenesis in Cervidae during developmental and seasonal changes.

Three steroidogenic enzymes, P450scc, P450c17 and 3 $\beta$ HSD, which are essential for the synthesis of sex steroid hormones, are localized not only in the Leydig cells but also in other testicular cells, such as Sertoli cells and spermatogenic cells in the monkey [27], American black bear [12], Japanese black bear [28], Hok- 


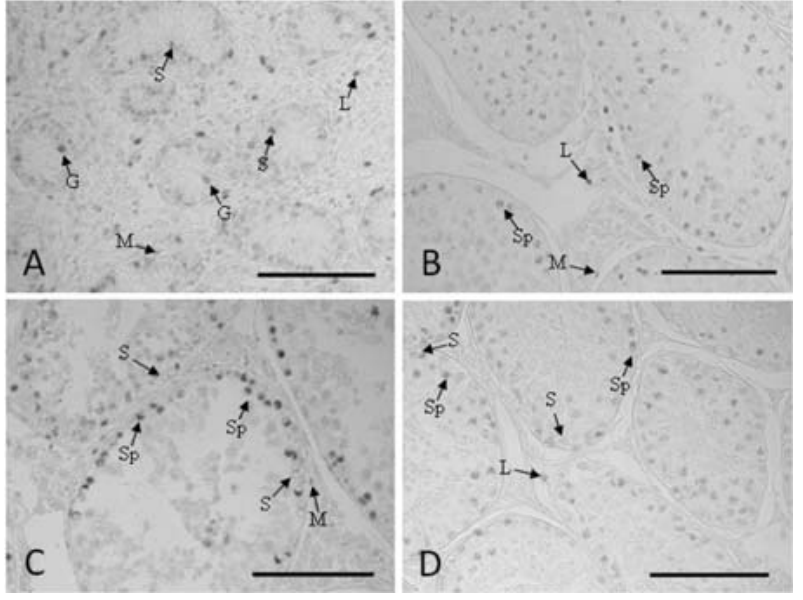

Fig. 6. Immunohistochemical localization of PCNA in the testes of the sika deer. Immunoreactivity for PCNA is detected in the Leydig cells, germ or spermatogenic cells and myoid cells during all developmental stages. However, in Sertoli cells, immunolocalization of PCNA is only found in the fetus and fawn stages. Differences in localization were not found during the different seasonal periods. (A) Fetus, (B) yearling, (C, D) adult (C, November; D, March). L: Leydig cells G: Germ cells M: Myoid cells S: Sertoli cells Sp: Spermatogenic cells. Bar $=100 \mu \mathrm{m}$.

kaido brown bear [26] and Japanese raccoon dog [25]. However, in the rat [29] and goat [15], these enzymes are detected only in the Leydig cells, in accordance with the present results. On the other hand, P450arom, the enzyme that converts testosterone to estradiol, is localized in various testicular cell types, such as Leydig cells, Sertoli cells and spermatogenic cells, of many mammals [6] including the American black bear [12], Japanese black bear [28, 30], Hokkaido brown bear [16], northern fur seal [13], Japanese raccoon dog [25], mouse [31] and rat [32]. However, in the sika deer, P450arom was localized only in the Leydig cells. This result was in accordance with the human [33], stallion [34, 35], ram [14], boar [17] and goat [15]. In the present study on sika deer testes, all of the steroidogenic enzymes examined were found only in the Leydig cells, suggesting that the Leydig cells may be the main testicular cells for production of sex steroid hormones, such as testosterone and estradiol.

In terms of the relationship between developmental changes and the syntheses of sex steroid hormones, the present results for the immunolocalization of P450scc, P450c17 and 3 $\beta$ HSD suggest that testosterone synthesis is already occurring in the fetal period in the Leydig cells of sika deer testes. Fetal testosterone synthesis has been demonstrated in the rat [29, 36], sheep [37], pig [38] and goat [15]. Testosterone is essential for male sexual differentiation and growth of male genital organs in the fetal period. In neonatal mouse testes, O’Shaughnessy et al. [16] reported that $17 \beta \mathrm{HSD}$, which directly converts androstenedione to testosterone, is expressed at 10 days of age, disappears at 20 days, and then reappears with increased expression at 30 days. In the bull, the testosterone concentrations reach a minimum at 1 month of postnatal age and were restored again at 2 months [39]. In further studies of the sika deer, it would be valuable to examine the changes in steroidogenesis during neonatal testicular development.

In the sika deer, estradiol is considered to be synthesized in the Leydig cells of yearling and adult testes because of the existence of P450arom. In the present histological observations, spermatogenesis started in yearlings. Therefore, in sika deer testes, we suggest that estrogen, mainly estradiol, is synthesized by the Leydig cells from at the least the yearling stage and has an influence on spermatogenesis and spermiogenesis. In previous reports, it has been mentioned that estrogen might have an effect on germ cell development via the estrogen receptor (ER) [40, 41]. On the other hand, in the goat, immunoreactivity for P450arom has also been found in fetal and neonatal testes [15]. Moreover, aromatase is expressed in the Leydig cells and Sertoli cells of fetal rodent testes, [40] and in the gonocytes and Leydig cells of fetal pig testes [42]. In fetal rat testes, estradiol promotes the proliferation of gonocytes [43] and has an effect on steroidogenic factor-1 (SF-1), which is important for gonadal differentiation and fetal Leydig cell functions [36]. Therefore, in the fetal period, estradiol is considered to be essential for fetal testicular development. However, in the fetal sika deer testes, immunoreactivity for P450arom was not detected. There are two possible explanations for these findings. One is that fetal sika deer depend on estradiol from maternal sources such as the placenta or ovary. The other is that estradiol synthesis and secretion may occur at an earlier fetal age than examined and then discontinues from the late fetal stage until the yearling stage.

In the present study on testicular seasonal changes, it was found that the interstitial area occupied by the Leydig cells was wider in the breeding season (October and November) than in the nonbreeding season (January, March, and July). Furthermore, the seminiferous tubules were largely developed with increasing numbers of the spermatogenic cells and spermatozoa in the breeding season. This result corresponds with a previous report that the diameter of the seminiferous tubules of sika deer testes is significantly increased in the breeding season [2]. These seasonal histological changes of sika deer testes in the breeding season occur simultaneously with the increase in the serum testosterone concentration [10].

In immunohistochemical examinations, the localization of steroidogenic enzymes in the sika deer has been restricted to the Leydig cells throughout the seasonal changes, whereas the localization of enzymes in the bear [28] and Japanese raccoon dog [25] changed seasonally. In the sika deer, the intensity of immunoreactivity for each steroidogenic enzyme shows seasonal changes like other seasonal breeders, of which the intensity is increased when the testes are fully active [12, 44].

With regard to the seasonal testicular cell proliferation of the Leydig cells in yearlings and adults, there were only small number of PCNA-immunoreactive Leydig cells in each season. In adult roe deer testes, Leydig cells do not proliferate, while the size of the testes increases in the breeding season [45]. These results corresponded with the present observations in sika deer testes. Therefore, we suggest that enlarged Leydig cells have increased testosterone synthesis per active cell with increased levels of steroidogenic enzymes, which increase the whole quantity of testicular testosterone in the breeding season. Sertoli cells showed 
PCNA immunoreactivity in fetuses and fawns, but not in yearlings or adults. In rat testes, it has been reported that the proliferation of the Sertoli cells is active during the perinatal period but not in the adult [46-48]. These previous results concur with those of the present research.

In the reindeer [8] and white-tailed deer [7], the male estradiol levels reach a maximum at the peak of the rut. The change in the estradiol concentration synchronized with the rut is similar to the case with testosterone. It is well-known that estradiol is directly converted from testosterone by P450arom. In the present study, almost all the enlarged Leydig cells in the breeding season showed P450arom immunoreactivity. This result suggests that sika deer testes might exhibit increased estradiol synthesis for spermatogenesis in the breeding season by conversion of the increased levels of testosterone. Tsubota et al. [12] reported a close relationship between the recrudescence of spermatogenesis and estradiol synthesis in the black bear. In male sika deer, the changes in serum estradiol levels and ER expression in testicular cells, including the spermatogenic cells, have not yet been examined. It is essential for understanding the role of estradiol in the recrudescence of spermatogenesis to clarify the relationship between the seasonal changes in serum estradiol and the ER testicular expressions in male sika deer.

In conclusion, the results of the present study indicate that testicular steroidogenesis of the sika deer occurs in the Leydig cells, which increases the levels of steroidogenic enzymes within the enlarged cytoplasm in the breeding season. Furthermore, they suggest that estradiol synthesized in yearling and adult testes makes a contribution to the initiation and recrudescence of spermatogenesis and spermiogenesis in the sika deer.

\section{Acknowledgments}

The present study was supported by a Grant-in-Aid for Scientific Research (The 21st Century Center-of-Excellence Program) from the Ministry of Education, Culture, Sports, Science and Technology of Japan (E-1). The authors would like to thank the Nishiokoppe Wildlife Association, Deer Farming Group, Village Office of Nishiokoppe, Yezo Deer Association, Obihiro and Okoppe branches of the Hokkaido Hunting Association, Town Office of Ashoro and members of the Deer sampling team of Hokkaido University for kind support in collecting the samples.

\section{References}

1. Lincoln GA. The seasonal reproductive changes in the red deer stag (Cervus elaphus). J Zool Lond 1971; 163: 105-123.

2. Suzuki M, Kaji K, Nigi $\mathbf{H}$. Annual changes of testis size, seminiferous tubules and plasma testosterone concentration of wild Sika deer (Cervus nippon yesoensis Heude, 1884) in Hokkaido. J Vet Med Sci 1992; 54: 551-556.

3. Payne AH, Hales DB. Overview of steroidogenic enzymes in the pathway from cholesterol to active steroid hormones. Endocr Rev 2004; 25: 947-970.

4. Dohle GR, Smit M, Weber RFA. Androgens and male fertility. World J Urol 2003; 21: 341-345.

5. Delbés G, Levacher C, Habert R. Estrogen effects on fetal and neonatal testicular development. Reproduction 2006; 132: 527-538.

6. Hess RA, Carnes $\mathbf{K}$. The role of estrogen in testis and the male reproductive tract: a review and species comparison. Anim Reprod 2004; 1: 5-30.

7. Bubenik GA, Bubenik AB, Zamecnik J. The development of circannual rhythm of estradiol in plasma of white-tailed deer (Odocoileus virginianus). Comp Biochem Physiol A Comp Physiol 1979; 62: 869-872.

8. Bubenik GA, Schams D, White RJ, Rowell J, Blake J, Bartos L. Seasonal levels of reproductive hormones and their relationship to the antler cycle of male and female reindeer (Rangifer tarandus). Comp Biochem Physiol B Biochem Mol Biol 1997; 116: 269277.

9. Johnson L, Thompson DL Jr. Age-related and seasonal variation in the Sertoli cell population, daily sperm production and serum concentrations of follicle stimulating hormone, luteinizing hormone and testosterone in stallions. Biol Reprod 1983; 29: $777-$ 789

10. Kameyama Y, Miyamoto A, Kobayashi S, Kuwayama T, Ishijima Y. Annual changes in serum $\mathrm{LH}$ and testosterone concentrations in male sika deer (Cervus nippon). J Reprod Dev 2002; 48: 612-617.

11. Lincoln GA, Davidson W. The relationship between sexual and aggressive behaviour, and pituitary and testicular activity during the seasonal sexual cycle of rams, and the influence of photoperiod. J Reprod Fertil 1977; 49: 267-276.

12. Tsubota T, Howell-Skalla L, Nitta H, Osawa Y, Mason LI, Meiers PG, Nelson RA, Bahr JM. Seasonal changes in spermatogenesis and testicular steroidogenesis in the male black bear (Ursus americanus). J Reprod Fertil 1997; 109: 21-27.

13. Tsubota T, Nagashima T, Kohyama K, Murase T, Kita I. Seasonal changes in testicular steroidogenesis and spermatogenesis in a northern fur seal, Callorhinus ursinus. J Reprod Dev 2001; 47: 415-420.

14. Bilinska B, Leśniak M, Schmalz B. Are ovine Leydig cells able to aromatize androgens? Reprod Fertil Dev 1997; 9: 193-199.

15. Weng Q, Medan MS, Ren L, Watanabe G, Tsubota T, Taya K. Immunolocalization of steroidogenic enzymes in the fetal, neonatal and adult testis of the shiba goat. Exp Anim 2005; 54: 451-454.

16. O'Shaughnessy PJ, Baker PJ, Heikkilä M, Vainio S, McMahon AP. Localization of $17 \beta$-hydroxysteroid dehydrogenase/17-ketosteroid reductase isoform expression in the developing mouse testis-androstenedione is the major androgen secreted by fetal/neonatal Leydig cells. Endocrinology 2000; 141: 2631-2637.

17. Fraczek B, Kotula-Balak M, Wojtusiak A, Pierscinski A, Bilinska B. Cytochrome P450 aromatase in the testis of immature and mature pigs. Reprod Biol 2001; 1: 51-59.

18. Hayakawa D, Sasaki M, Akabane C, Kitamura N, Tsubota T, Suzuki M, Yamada J Immunohistochemical localization of steroidogenic enzymes in the testis of Hokkaido Sika deer (Cervus nippon yesoensis). J Vet Med Sci 2004; 66: 1463-1466.

19. Onuma M, Takahashi $\mathbf{H}$, Asano $\mathbf{M}$, Ueno M, Suzuki M, Kaji K. The capture and chemical immobilization of wild Hokkaido sika deer (Cervus nippon yesoensis). Jpn J Zoo Wildl Med 2005; 10: 19-26.

20. Suzuki M. Studies on immobilization techniques, reproduction and growth in wild sika deer (Cervus nippon) in Japan. Doctoral Thesis, Hokkaido Univ. 1994 (In Japanese).

21. Suzuki M, Kaji K, Yamanaka M, Ohtaishi N. Gestational age determination, variation of conception date, and external fetal development of sika deer (Cervus nippon yesoensis Heude, 1884) in eastern Hokkaido. J Vet Med Sci 1996; 58: 505-509.

22. Ohtaishi N. Determination of sex, age and death-season of recovered remains of Sika deer (Cervus nippon) by jaw and tooth-cement. Archaeol Nat Sci 1980; 13: 51-74 (In Japanese).

23. Matsuura Y, Sato K, Suzuki M, Ohtaishi N. The effects of age, body weight and reproductive status on conception dates and gestation periods in captive sika deer. Mammal Study 2004; 29: 15-20.

24. Hsu SM, Raine L, Fanger H. Use of avidin-biotin-peroxidase complex (ABC) in immunoperoxydase techniques: a comparison between $\mathrm{ABC}$ and unlabeled antibody (PAP) procedures. J Histochem Cytochem 1981; 29: 577-580.

25. Qiang W, Murase T, Tsubota T. Seasonal changes in spermatogenesis and testicular steroidogenesis in wild male raccoon dogs (Nyctereutes procynoides). J Vet Med Sci 2003, 65: 1087-1092.

26. Tsubota T, Nitta H, Osawa Y, Mason J, Kita I, Tiba T, Bahr JM. Immunolocalization of steroidogenic enzymes, P450scc, 3 $\beta$ HSD, P450arom in the Hokkaido brown bear (Ursus arctos yesoensis) testis. Gen Comp Endocrinol 1993; 92: 439-444.

27. Liang JH, Sankai T, Yoshida T, Cho F, Yoshioka Y. Localization of testosterone and $3 \beta$-hydroxysteroid dehydrogenase $/ \Delta^{5}$ - $\Delta^{4}$-isomerase in cynomolgus monkey (Macaca fascicularis) testes. J Med Primatol 1998; 27: 10-14

28. Okano T, Murase T, Tsubota T. Spermatogenesis, serum testosterone levels and immunolocalization of steroidogenic enzymes in the wild male Japanese black bear (Ursus thibetanus japonicus). I Vet Med Sci 2003; 65: 1093-1099.

29. Pelletier G, Li S, Luu-The V, Tremblay Y, Bélanger A, Labrie F. Immunoelectron microscopic localization of three key steroidogenic enzymes (cytochrome $\mathrm{P}_{450} \mathrm{scc}_{\mathrm{sc}} 3 \beta$ hydroxysteroid dehydrogenase and cytochrome $\left.\mathrm{P} 450_{\mathrm{c} 17}\right)$ in rat adrenal cortex and gonads. J Endocrinol 2001; 171: 373-383.

30. Komatsu T, Tsubota T, Yamamoto Y, Atoji Y, Suzuki Y. Seasonal changes in the immunolocalization of steroidogenic enzymes in the testes of the Japanese black bear 
(Ursus thibetanus japonicus). J Vet Med Sci 1997; 59: 521-529.

31. Nitta H, Bunick D, Hess RA, Janulis L, Newton SC, Millette CF, Osawa Y, Shizuta Y, Toda K, Bahr JM. Germ cells of the mouse testis express P450 aromatase. Endocrinology 1993; 132: 1396-1401.

32. Levallet J, Bilinska B, Mittre H, Genissel C, Fresnel J, Carreau S. Expression and immunolocalization of functional cytochrome $\mathrm{P} 450$ aromatase in mature rat testicular cells. Biol Reprod 1998; 58: 919-926.

33. Inkster S, Yue W, Brodie A. Human testicular aromatase: immunocytochemical and biochemical studies. J Clin Endocrinol Metab 1995; 80: 1941-1947.

34. Eisenhauer KM, McCue PM, Nayden DK, Osawa Y, Roser JF. Localization of aromatase in equine Leydig cells. Domest Anim Endocrinol 1994; 11: 291-298.

35. Hess MF, Roser JF. Immunocytochemical localization of cytochrome P450 aromatase in the testis of prepubertal, pubertal, and postpubertal horses. Theriogenology 2004; 61: 293-299.

36. Majdic G, Saunders PT, Teerds KJ. Immunoexpression of the steroidogenic enzymes 3-beta hydroxysteroid dehydrogenase and $17 \alpha$-hydroxylase, C17,20 lyase and the receptor for luteinizing hormone $(\mathrm{LH})$ in the fetal rat testis suggests that the onset of Leydig cell steroid production is independent of LH action. Biol Reprod 1998; 58: 520525.

37. Quirke LD, Juengel JL, Tisdall DJ, Lun S, Heath DA, McNatty KP. Ontogeny of steroidogenesis in the fetal sheep gonad. Biol Reprod 2001; 65: 216-228.

38. Moran FM, Ford JJ, Corbin CJ, Mapes SM, Njar VC, Brodie AM, Conley AJ. Regulation of microsomal P450, redox partner proteins, and steroidogenesis in the developing testes of the neonatal pig. Endocrinology 2002; 143: 3361-3369.

39. Schams D, Shallenberger E, Gombe S, Karg H. Endocrine patterns associated with puberty in male and female cattle. J Reprod Fert Suppl 1981; 30: 103-110.

40. Akingbemi BT. Estrogen regulation of testicular function. Reprod Biol Endocrinol 2005;
3: 51 .

41. O'donnell L, Robertson KM, Jones ME, Simpson ER. Estrogen and spermatogenesis Endocr Rev 2001; 22: 289-318.

42. Häußler S, Wagner A, Welter H, Claus R. Changes of testicular aromatase expression during fetal development in male pigs (Sus scrofa). Reproduction 2007; 133: 323-330.

43. Li H, Papadopoulos V, Vidic B, Dym M, Culty M. Regulation of rat testis gonocyte proliferation by platelet-derived growth factor and oestradiol: identification of signaling mechanisms involved. Endocrinology 1997; 138: 1289-1298.

44. Lincoln GA. Seasonal aspects in testicular function. In: Burger H, de Kretser D (eds.), The Testis, $2^{\text {nd }}$ ed. New York: Raven Press; 1989: 329-385.

45. Schön J, Göritz F, Streich J, Blottner S. Histological organization of roe deer testis throughout the seasonal cycle: variable and constant components of tubular and interstitial compartment. Anat Embryol 2004; 208: 151-159.

46. Clermont Y, Perey B. Quantitative study of the cell population of the seminiferous tubules in immature rats. Am J Anat 1957; 100: 241-269.

47. Orth JM. Proliferation of Sertoli cells in fetal and postnatal rat: a quantitative autoradiographic study. Anat Rec 1982; 203: 485-492.

48. Sasaki M, Yamamoto M, Arishima K, Eguchi Y. Effect of follicle-stimulating hormone on Sertoli cell division in cultures of fetal rat testes. Biol Neonate 2000; 78: 48-52.

49. Hales DB, Sha L, Payne AH. Testosterone inhibits camp-induced de novo synthesis of Leydig cell cytochrome P450 17 $\alpha$ by an androgen receptor-mediated mechanism. J Biochem 1987; 103: 106-113.

50. Doody KM, Carr BR, Reiney WE, Byrd W, Murry BA, Strichler RC, Thomas JL, Mason JI. $3 \beta$-hydroxysteroid dehydrogenase/isomerase in the fetal zone and neocortex of the human fetal adrenal gland. Endocrinology 1990; 126: 2487-2492.

51. Kitawaki J, Yoshida N, Osawa Y. An enzyme-linked immunosorbent assay for quantitation of aromatase cytochrome P450. Endocrinology 1989; 124: 1417-1423. 